\title{
Late Quaternary freshwater dinoflagellate cysts from the British Isles
}

\author{
CHRIS O. HUNT, MARTHA V. ANDREWS \& DAVID D. GILBERTSON \\ Department of Prehistory and Archaeology, The University of Sheffield, Sheffield S10 2TN, U.K.
}

\begin{abstract}
Two species of peridinioid dinoflagellate cyst are described from Late Quaternary lacustrine and fluvial deposits in England and Scotland. Saeptodinium skipseaense sp. nov. has a bipesoid tabulation and a hemiepicystal archaeopyle. Colonsaydinium psilatum gen. et sp. nov. has a compound archaeopyle interpreted as $213 \mathrm{P}\left(1-2 \mathrm{i} 3-5^{\prime \prime}\right)$. The morphology of the archaeopyle suggests that this may be the cyst of a species with cinctoid tabulation. Both taxa are found only in sediment laid down in base-rich, non-turbulent, relatively deep fresh water.
\end{abstract}

\section{INTRODUCTION}

This paper describes fossil freshwater peridinioid dinoflagellate cysts from Late-Quaternary lacustrine and fluvial deposits in England and Scotland. Freshwater dinoflagellate cysts have not previously been reported from Quaternary deposits in Britain, but are known from Australia (Churchill \& Sarjeant, 1963; Harland \& Sarjeant, 1970; Harland, 1971) and the United States (Eisenack \& Fries, 1965; Norris \& McAndrews, 1970). Cysts of modern Peridinium spp. have been described by Eisenack \& Fries (1965), Evitt \& Wall (1968) and Boltovskoy (1973, 1976). Bujak \& Davies (1983) have recently reviewed the Suborder Peridiniineae, which encompasses all fossil and Recent peridinioid dinoflagellates and their cysts.

The dinoflagellate cysts were found in samples from sites of archaeological and stratigraphical interest during routine pollen analysis. The samples which yielded dinoflagellate cysts were re-prepared by boiling in $5 \%$ potassium hydroxide, sieving through $200 \mu \mathrm{m}$ and on $10 \mu \mathrm{m}$ nylon mesh and swirling on a clock-glass. Portions of the residues were boiled in an acetolysis mixture of 1 part concentrated sulphuric acid to 9 parts acetic anhydride, to ascertain whether the cysts were composed of sporopollenin. Samples of older Quaternary deposits from around the sites were prepared to check that the dinoflagellate cysts were not recycled. The samples were stained with safranin, mounted in glycerin jelly and sealed with cellulose dope (it was found that the dinoflagellate cysts collapsed when mounted using cellosize and Canada balsam).

The slides used in this study are stored in the Micropalaeontology Laboratory of the Department of Geology, University of Sheffield (Lab. nos. ML 1742-4).

\section{MATERIAL}

Dinoflagellate cysts were recovered from three Late Quaternary sections in England and one section in Scotland:
1. Skipsea Whittow, East Yorkshire (TA184546). Cliff sections show a sequence of Skipsea Till and outwash gravels of Devensian (Last Glacial) age, overlain by lacustrine silts of Late Devensian $(13,000-10,000$ years B.P.) age, overlain by Holocene detritus-muds and peats (Godwin \& Godwin, 1933; Catt, 1977; Gilbertson, Flenley, Hall, Hunt \& Woodall, 1984).

Dinoflagellate cysts were found 1-4 $\mathrm{m}$ below the clifftop in the lacustrine silts, where their distribution appears to reflect climatic influences. Higher incidences of cysts (calculated both as a percentage of Quaternary palynomorphs and as cysts per gram of sediment) were recovered from deposits laid down during temperate climatic intervals correlated with pollen zones Ib, II and the base of zone IV of Godwin (1975), than from the intervening deposits laid down under sub-arctic climates (Gilbertson et al., 1984).

2. Fiskerton, Lincolnshire (TF049716). Drainage ditches near the River Witham showed a Late Holocene fluvial sequence, with silty channel-fill deposits interdigitating with, and overlain by, overbank silts and backswamp peats (Gilbertson, D. D., Field, N. \& Groves, C. unpublished). Dinoflagellate cysts were found 0.7$0.9 \mathrm{~m}$ below the ground surface in silty channel-fill deposits overlain by peats and an Iron Age causeway radiocarbon dated to $2460 \pm 70$ radiocarbon years $B P$ (HAR4472; J. Hillam, C. Groves, pers. comm.).

3. Hazleslack, Lancashire (SD 476785). Shallow boreholes in a karstic closed depression-fill showed a Late Devensian and Holocene sequence of lacustrine silts overlain by marsh and fen peats ( Gale, S. J. \& Hunt, C. O., unpublished). Dinoflagellate cysts were recovered from the lacustrine silts at a depth of 3-5 $\mathrm{m}$. They were most common in samples assigned to pollen zone IV of Godwin (1975).

4. Loch Cholla, Colonsay, Argyllshire (NR382917). Shallow boreholes in the south side of the partially infilled Loch Cholla basin showed $5-6 \mathrm{~m}$ of peats and peaty silts of Holocene age (Andrews, in press). Dinoflagellate 
cysts were recovered from peaty silts at a depth of 5.5$6.0 \mathrm{~m}$, which by palynological comparison with a radiocarbon dated core from the neighbouring island of Oronsay, are about 9000 years old.

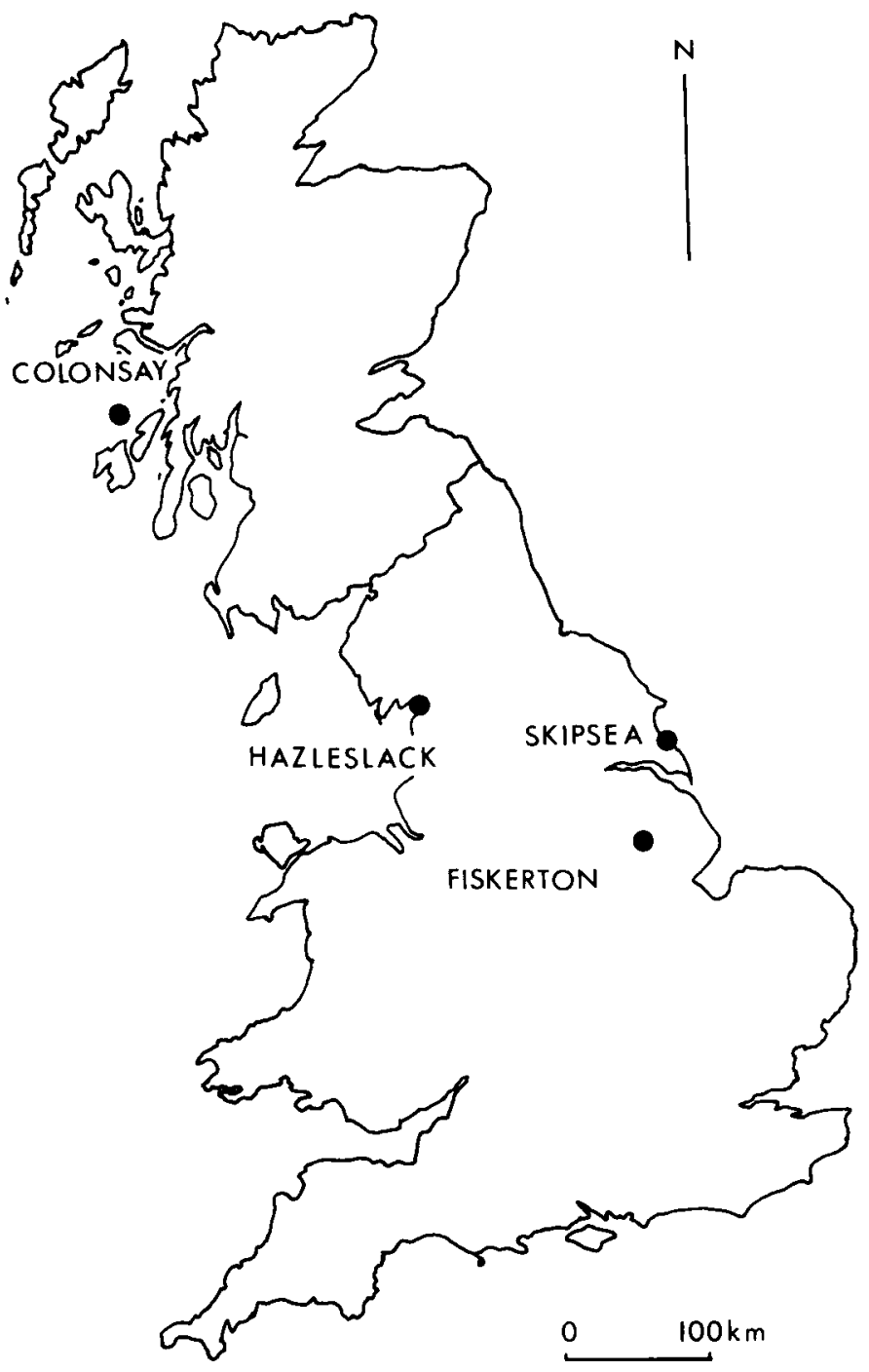

Fig. 1. British Isles location map showing freshwater dinoflagellate cyst localities.

\section{NOMENCLATURE}

A number of authors, including Norris \& McAndrews (1970), Reid (1974), Dale (1978), Bradford (1978) and Harland $(1982,1983)$ have discussed the nomenclature of Quaternary and Recent dinoflagellate cysts and the problem of the integration of cyst-based and thecabased taxonomic systems. No clear consensus has yet emerged as to the best procedure for handling the nomenclature of Quaternary dinoflagellate cysts.
A classification based on the morphology of the thecate stage of the dinoflagellate life cycle has traditionally been used by phycologists. In contrast, palynologists naming dinoflagellate cysts (and acritarchs) from Quaternary and Recent deposits have used a system of taxonomy based upon the morphology of the encysted stage of the dinoflagellate life-cycle which had been developed by Mesozoic and Tertiary palynologists. Except in very rare cases, the thecate stage is not preserved as a fossil.

Following the work of Wall \& Dale (1968) it became possible to establish some cyst/theca relationships by culturing modern cysts until the thecate stage developed. Wall \& Dale (1968), Dale (1978), Bradford (1978) and Harland $(1982,1983)$ have commented upon the desireability of the integration of cyst-based and thecabased taxonomic systems into a single system based upon the holomorph. Norris \& McAndrews (1970), Dale (1978), and Harland $(1982,1983)$ suggested that new cyst-based nomenclature should not be created to maintain a cyst-based taxonomy for Quaternary and Recent species, on the grounds that many cyst taxa may, in time, be found to be junior synonyms of thecate taxa, and that it is pointless to erect Linnean taxonomy that is potentially unstable.

Reid (1974) and Bradford $(1975,1978)$ have argued that cyst-based Linnean taxonomy should be used until a taxonomic system based upon the holomorph is available. They argue that, for geological purposes, cyst based nomenclature has advantages over that based upon the thecate stage or upon the holomorph, since there is continuity with the geological record.

Linnean taxonomy is the universally agreed tool used to classify organisms. We prefer to regard Quaternary cysts as part of the fossil record and therefore formally assign the cysts decribed here to cyst-based form-taxa, rather than leave them in open nomenclature as cysts of unknown thecate species probably of the thecate genus Peridinium Ehrenberg. We feel that it is undesirable to use a non-Linnean system to classify Quaternary dinoflagellate cysts until thecate equivalents are found, as advocated by Norris \& McAndrews (1970) and Dale (1978), or to defer their formal description, as practised by Harland (1982), for the following reasons:

There may well be a considerable delay before culture proves the relationship between theca and cyst, during which time taxa would not be formally described. In the meantime, workers other than the finder of a particular cyst would not have a proper standard for comparison. There is thus the possibility of the proliferation of poorlyunderstood 'taxa'.

Some modern dinoflagellates may produce cysts only rarely, in which case it may be a long time before viable cysts are available for culturing. Others may require excystment conditions difficult to replicate in the laboratory. In either case, it may be impossible to estab- 
lish cyst/theca relationships for some dinoflagellates for many years.

The integration of thecal and cyst nomenclature may prove problematical. Dale (1978) has pointed out that thecal taxonomy is, in some cases, 'underclassified'. For instance, Gonyaulax spinifera (Claparède \& Lachmann) Diesing is the thecate equivalent of at least six morphologically and ecologically separate cyst taxa (Reid \& Harland, 1977; Harland, 1983). Bradford (1978) argues against the assignment of 'well-defined cyst morphotypes to poorly defined and poorly understood thecate holomorphs'.

There is a tendency to regard the Quaternary as an interval too short for evolution to have taken place. Unless Quaternary taxa are rigorously defined, rather than referred to broadly similar modern genera and species, this hypothesis cannot be tested. Moreover, even if cyst morphology has remained constant, there is no way of knowing whether thecate morphology was similarly consistent.

The possibility exists that even Late Quaternary dinoflagellates may now be extinct. The taxa reported here are certainly locally extinct, and have not been encountered in the sediments of modern lakes, reservoirs and rivers, in the British Isles.

\section{NOTE ON DESCRIPTIVE TERMINOLOGY}

Following Norris (1978) and Bujak \& Davies (1983, p. 18) the use of the prefix 'para-' is considered superfluous and is not used when describing cyst morphology.

\section{SYSTEMATIC DESCRIPTIONS}

Division Pyrrhophyta Pascher, 1914

Class Dinophyceae Fritsch, 1929

Order Peridiniales Haeckel, 1894

Family Peridiniaceae (Ehrenberg) Bujak \& Davies, 1983

Genus Saeptodinium Harris, 1973

Type species. Saeptodinium gravattense Harris, 1973.

Saeptodinium skipseaense Hunt sp. nov.

(Pl. 1, figs. 1-9; Pl. 2, figs. 1-3; Fig. 2)

Diagnosis. Large proximate dinoflagellate cysts exhibiting varying degrees of cavation. Pericyst rounded peridinioid, with a rounded epicyst and two blunt antapical horns. Endocyst rounded peridinioid to ovoid. Periphragm psilate, thin $(0.1 \mu \mathrm{m}$ on SEM) . Endophragm psilate to faintly scabrate, thin $(0.3 \mu \mathrm{m}$ on SEM). Tabulation $4^{\prime} 3 \mathrm{i} 5^{\prime \prime} 7^{\prime \prime} 2^{\prime \prime \prime}$, indicated by very narrow, shallow $(0.1 \mu \mathrm{m}$ on SEM) grooves on the outer surface of the endophragm, occasionally also by irregular cracks on the periphragm (seen only in SEM). Cingulum laevorotary, displaced one or two times its breadth, $6-11 \mu \mathrm{m}$ broad, often bordered by small pericoels, occasionally by very low, $(0.2 \mu \mathrm{m}$ on SEM) smooth topped ridges on the periphragm. ?Flagellar slit 7-15 $\mu \mathrm{m}$ long, 1-2 $\mu \mathrm{m}$ wide, with a slightly thickened edge, lies on the sulcus between the ends of the cingulum. Sulcus broad, short and straight sided. Archaeopyle hemiepicystal, opening by a transapical suture and a suture at the anterior edge of the cingulum. Operculum usually free, plates $3^{\prime}$ 1-3i 3-5".

$\begin{array}{lccc}\text { Dimensions (in } \mu \mathrm{m} \text { ) } & \text { Minimum } & \text { Mean } & \text { Maximum } \\ \text { Pericyst length } & 58 & 91 & 150 \\ \text { Pericyst breadth } & 50 & 68 & 120 \\ \text { Endocyst length } & 54 & 75 & 135\end{array}$

(15 specimens measured).

Holotype. Slide SK 39.1 England Finder reference D24.2. Pl. 1, figs. 2, 5, 8. Skipsea Whittow, Skipsea, East Yorkshire. (TA 184546), Late Devensian silts, Unit 3a of Gilbertson et al. (1984), $2.75 \mathrm{~m}$ below ground.

Remarks. This species is attributed to Saeptodinium Harris 1973 on the basis of its hemiepicystal archaeopyle and cavate, peridinioid morphology. It differs from $S$. gravattense Harris, $S$. tasmaniense Harris, S. eurypylum (Manum \& Cookson) Stover \& Evitt and $S$. hansonianum (Traverse) Stover \& Evitt by having a complete tabulation of grooves on the outside of the endocyst. It differs from the rather similar Type D cysts of Norris \& McAndrews (1970) by being larger and having a visible tabulation and in lacking the microreticulate ornament on the endophragm of that species It differs from the similar Type C cysts of Norris \& McAndrews (1970), which are identical in morphology and tabulation, by being larger and by having the tabulation on the outside, rather than the inside of the endophragm. It lacks the areolate ornament on the inside of the endophragm characteristic of Type $C$ cysts. The bipesoid tabulation (Fig. 2) and general morphology of Saeptodinium skipseaense suggests that it has close affinities with the Peridinium bipes group.

Distribution. Saeptodinium skipseaense is known from Late Devensian deposits at Skipsea Whittow, Early Holocene deposits at Hazleslack and Late Holocene deposits at Fiskerton.

Genus Colonsaydinium Hunt gen. nov.

Type species. Colonsaydinium psilatum sp. nov.

Diagnosis. Proximate, cornucavate to circumcavate dinoflagellate cysts with a rounded peridinioid outline. Tabulation poorly delineated except for combination archaeopyle. Operculum free, probably plates $1-2 i$ $3-5^{\prime \prime}$. 

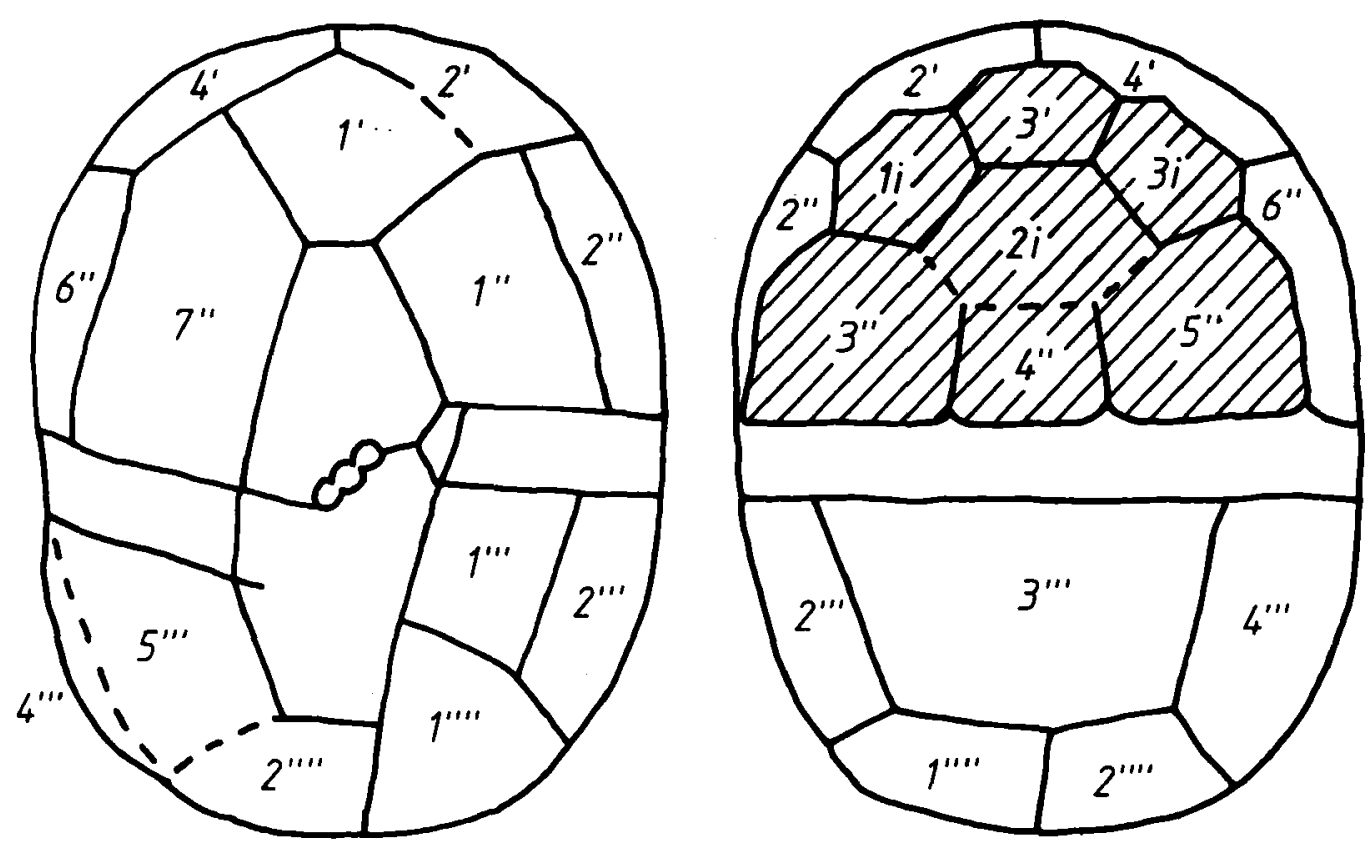

Fig. 2. Reconstructed tabulation of endocyst of Saeptodinium skipseaense sp. nov.

\section{Explanation of Plate 1}

All figures are $\times 500$, using transmitted light, unless indicated.

Figs. 1-9. Saeptodinium skipseaense sp. nov.

Figs. 1, 4, 7. SK 39.1, P32.1: fig. 1, Endocyst: low focus showing traces of tabulation, fig. 4, middle focus (Nomarski) showing sulcal slit fig. 7, high focus, showing archaeopyle.

Figs. 2, 5, 8. SK39.1, D24.2: fig. 2, Holotype: low focus, showing ventral surface and sulcal slit; fig. 5, middle focus, showing closely adpressed wall layers, peridinioid outline and apical margin of operculum, fig. 8, high focus, showing dorsal surface and cingular margin of operculum.

Fig. 3. SK39.1, F27.4. Middle focus, showing peridinioid outline and development of small pericoels at the apex, flanking the cingulum and at the antapical horns.

Fig. 6. SK39.1, D25.2. High focus, showing antapical horns, cingulum and archaeopyle.

Fig. 9. SK39 (SEM X 5000) Detail of sulcal slit. 

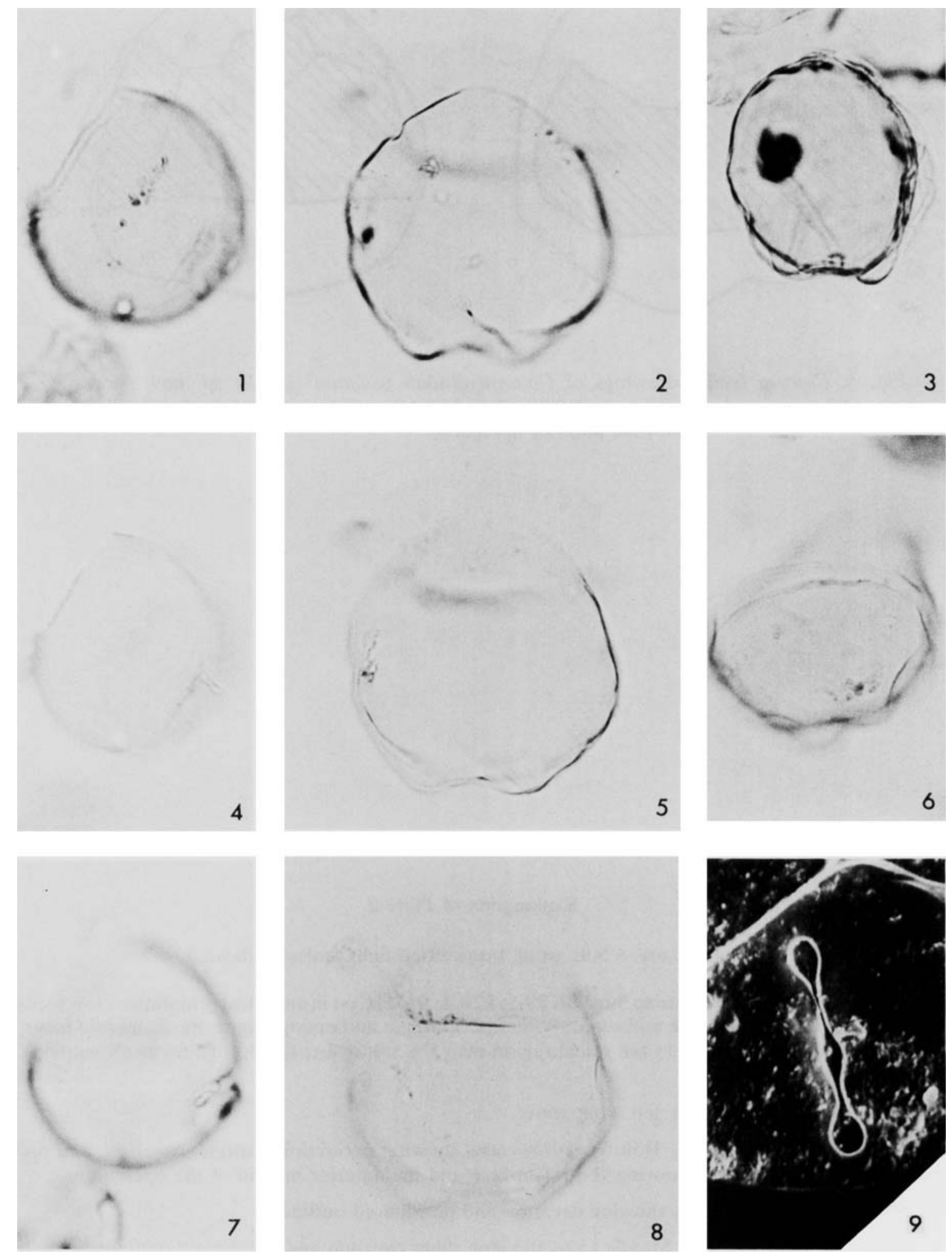

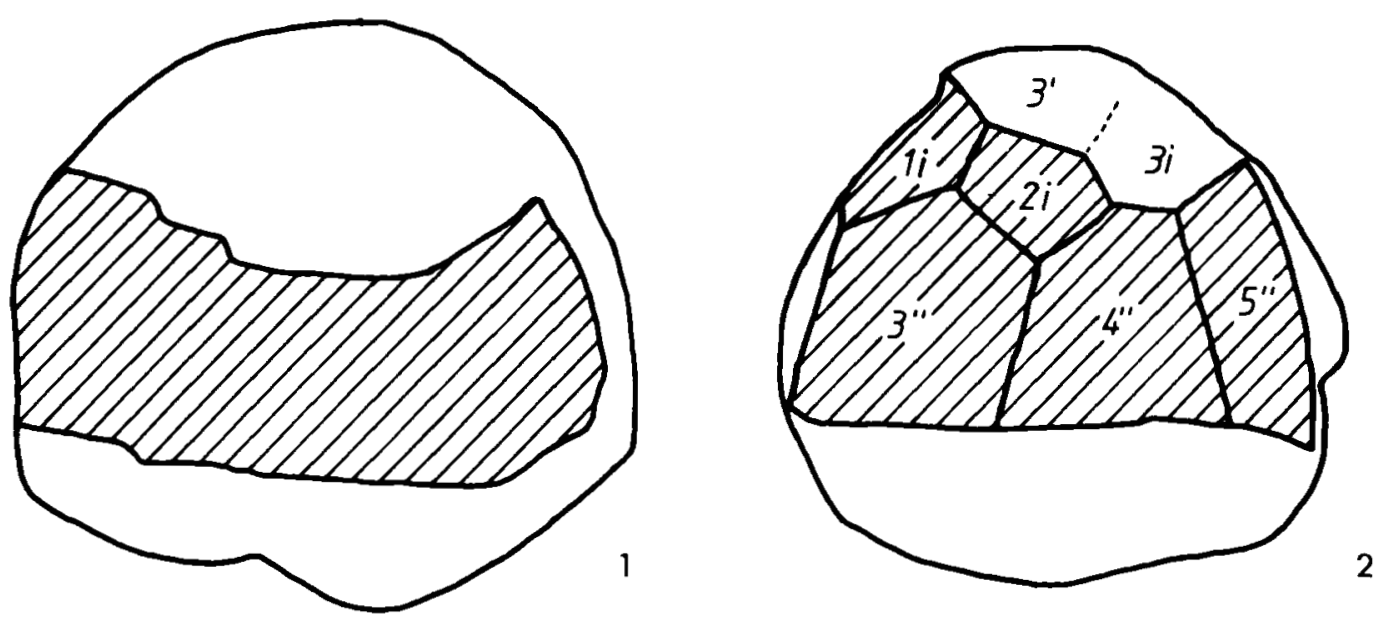

Fig. 3. Camera lucida drawings of Colonsaydinium psilatum gen. et sp. nov. showing archaeopyle morphology. 1) CC506.2, Q30.4; 2) CC506.1, G34.1, showing hypothetical reconstructed tabulation of operculum.

\section{Explanation of Plate 2}

All figures are $\times 500$, using transmitted light, unless indicated.

Figs. 1, 2,3. Saeptodinium skipseaense sp. nov. SK39.1, S26.2: fig. 1, Cyst in antapical orientation: low focus showing apex, hemiepicystal archaeopyle and separation of periphragm and endophragm; fig. 2, middle focus, showing cavation and wall relationships in the sulcal region near the sulcal slit; fig. 3, high focus (Nomarski), showing antapical tabulation.

Figs. 4-9. Colonsaydinium psilatum gen. et sp. nov.:

Figs. 4, 5. CC506.1, X22.3; fig. 4, Holotype; low focus showing peridinioid outline, cavation, and archaeopyle formation; fig. 5, high focus, showing ventral surface and the anterior margin of the operculum.

Fig. 6. CC506.1 Q22.1. Mid focus, showing cavation and peridinioid outline.

Figs. 7, 8. CC506.2, Q30.4: fig. 7, Middle focus showing slight cavation and peridinioid outline; fig. 8, low focus, showing dorsal surface and asymmetrical, compound archaeopyle.

Fig. 9. CC506.1. G34.1, High focus, showing distal surface and asymmetrical, compound archaeopyle of endocyst. 

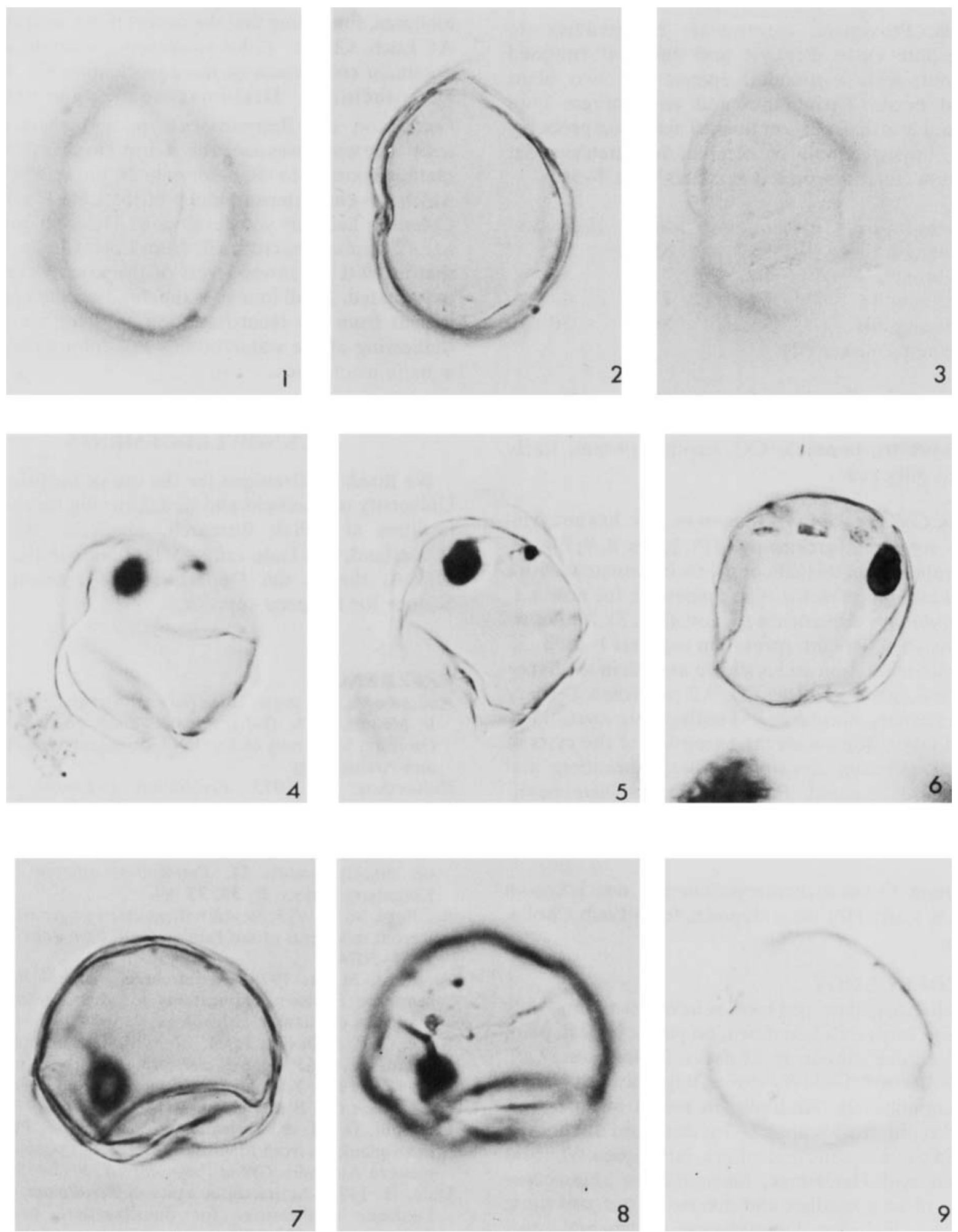
Colonsaydinium psilatum Hunt sp. nov. (Pl. 2, figs. 4-9; Fig. 3)

Diagnosis. Proximate, cornucavate to circumcavate dinoflagellate cysts. Pericyst and endocyst rounded peridinioid, with a rounded epicyst and two blunt antapical horns. Periphragm and endophragm both psilate and less than $0.5 \mu \mathrm{m}$ thick. Tabulation probably cinctoid, indicated only by combination archaeopyle. Operculum free, interpreted as plates $1-2 i$ 3-5".

$\begin{array}{lccc}\text { Dimensions (in } \mu \mathrm{m} \text { ) } & \text { Minimum } & \text { Mean } & \text { Maximum } \\ \text { Pericyst length } & 78 & 83 & 94 \\ \text { Pericyst breadth } & 60 & 73 & 84 \\ \text { Endocyst length } & 72 & 77 & 88 \\ \text { Endocyst breadth } & 56 & 66 & 76\end{array}$

(14 specimens measured).

Holotype. Slide CC506.1, England Finder reference (X22.3). Pl. 2. figs. 4, 5. Loch Cholla, Colonsay, (NR38249170), borehole CC, depth $5.06 \mathrm{~mm}$, Early Holocene silty peat.

Remarks. Colonsaydinium psilatum sp. nov. has an asymmetrical, compound archaeopyle (PI. 2, figs. 8, 9; Fig. 3). The morphology of this achaeopyle is inconsistent with a bipesoid tabulation of the type possessed, for instance, by Saeptodinium skipseaense sp. nov. (Fig. 2). It is, however, consistent with interpretation as plates $1-2 i, 3-5$ " of a cintoid tabulation and is shown as such in the hypothetical reconstruction (Fig. 3). All published Tertiary and Quaternary freshwater dinoflagellate cysts have bipesoid tabulations, with the exception of the cysts of modern Peridinium cinctum (Müller) Ehrenberg and $P$. gatunense Nygaard. $P$. cinctum cysts have hemiepicystal archaeopyles, while $P$. gatunense cysts have epicystal archaeopyles (Boltovskoy, 1973, 1975).

Distribution. Colonsaydinium psilatum sp. nov. is known only from Early Holocene deposits from Loch Cholla, Colonsay.

\section{PALAEOECOLOGY}

Both dinoflagellate cyst species have been found only in silts and silty peats laid down, on palynological, plant macrofossil and molluscan evidence (Gilbertson et al., 1984; Gilbertson, Field \& Groves, unpublished; Gale \& Hunt, unpublished; Andrews, in press) in base-rich, non-turbulent, fresh water, $1-5 \mathrm{~m}$ deep and not heavily colonised by an aquatic macroflora. At Skipsea Whittow, Fiskerton and Hazleslack, Saeptodinium skipseaense was part of an abundant and diverse microfossil flora, which also included Desmidaceae, Zygnemataceae, Pediastrum sp., Botryococcus sp. and algae incertae sedis. The water-bodies at these three sites were calcareous. The water-bodies at the former two sites were well-oxygenated; the silts from these sites contain abundant benthic mollusca. In contrast, the deposits from Hazleslack, although calcareous, do not contain mollusca, suggesting that the waters there were stagnant. At Loch Cholla, Colonsaydinium psilatum was the dominant component of the aquatic microflora, which also included Diatomaceae, Zygnemataceae, Pediastrum sp., Botryococcus sp. and algae incertae sedis. The water was probably neutral to slightly basic, in marked contrast to the modern loch; the acid heathland which has characterised much of the Late Holocene of Colonsay had not yet developed. The well-preserved nature of plant macrofossils from Loch Cholla suggests that at least the lower levels of the Loch were poorly oxygenated. At all four sites the dinoflagellate cysts disappear from the record as soon as there are signs of shallowing of the water-bodies and colonisation by an aquatic macroflora.

\section{ACKNOWLEDGEMENTS}

We thank K. Branigan for the use of facilities at the University of Sheffield and K. J. Dorning for the use of facilities at Pallab Research, Sheffield. We thank R. Harland, S. J. Gale and K. J. Dorning for discussions. M.V.A. thanks the Department of Education and Science for financial support.

\section{REFERENCES}

Andrews, M. V. In press. Three pollen diagrams from Colonsay. In Mellars, P. A. (Ed.), The Mesolithic Shell-Middens of Oronsay. University of Sheffield Monographs in Prehistory and Archaeology.

Boltovskoy, A. 1973. Peridinium gatunense Nygaard. Estructura y estereoultraestructura tecal (Dinoflagellida). Physis, B, 32, 331-344.

Boltovskoy, A. 1975. Estructura y estereoultraestructura tecal de dinoflagelados. II. Peridinium cinctum (Müller) Ehrenberg. Physis, B, 34, 73-84.

Bradford, M. R. 1975. New dinoflagellate cyst genera from the Recent sediments of the Persian Gulf. Can. Jour. Bot., 53, 3064-3074.

Bradford, M. R. 1978. Acritarchous cysts of Peridinium faeroense Paulsen: implications for dinoflagellate systematics. A discussion. Palynology, 2, 195-198.

Bujak, J. P. \& Davies, E. H. 1983. Modern and fossil Peridiniineae. AASP Contrib. Ser., 13, 203 pp., 12 pl.

Catt, J. A. 1977. Yorkshire and Lincolnshire. Guidebook for Excursion C7. Birmingham. INQUA. $56 \mathrm{pp.}$

Churchill, D. M. \&. Sarjeant, W. A. S. 1963. Freshwater microplankton from Flandrian (Holocene) peats of southwestern Australia. Grana Palynologica, 3, 29-53.

Dale, B. 1978. Acritarchous cysts of Peridinium faeroense Paulsen: implications for dinoflagellate systematics. Palynology, 2, 187-193.

Eisenack, A. \& Fries, M. 1965. Peridinium limbatum (Stokes) verglichen mit der tertiären Deflandrea phosphoritica Eisenack. Geol. Fören. Stockholm Forhandl., 87, 239-248. 
Evitt, W. R. \& Wall, D. 1968. Dinoflagellate studies IV. Theca and cyst of Recent freshwater Peridinium limbatum (Stokes) Lemmermann. Stanford Univ. Pubs., Geol. Sci., 12(2), $1-15$.

Gilbertson, D. D., Flenley, J. R., Hall, A. R., Hunt, C. O. \& Woodall, D. 1984. Late Quaternary Environments and Man in Holderness. Oxford. B A R.

Godwin, H. 1975. The History of the British Flora. (2nd ed.) Cambridge. Cambridge University Press.

Godwin, H. \& Godwin, M. E. 1933. British Maglemose harpoon sites. Antiquity, 7, 36-48.

Harland, R. 1971. Fossil dinoflagellate cysts from Lake Gnotuk, Victoria, Australia. Proc. Roy. Soc. Victoria, 84, 245-254.

Harland, R. 1982. A review of Recent and Quaternary organicwalled dinoflagellate cysts of the genus Protoperidinium. Palaeontology, London, 25, 369-397.

Harland, R. 1983. Distribution maps of Recent dinoflagellate cysts in bottom sediments from the North Atlantic ocean and adjoining areas. Palaeontology, London, 26, 2, 321-387.
Harland, R. \& Sarjeant, W. A. S. 1970. Fossil freshwater microplankton (dinoflagellates and acritarchs) from Flandrian (Holocene) sediments of Victoria and Western Australia. Proc. Roy. Soc. Victoria, 83, 211-234.

Norris, G. 1978. Phylogeny and a revised supra-generic classification for Triassic-Quaternary organic-walled dinoflagellate cysts (Pyrrhophyta). Part I. Cyst terminology and assessment of previous classifications. $N$. Jb. Geol. Paleont. Abh., 155, 3, 300-317.

Norris, G. \& McAndrews. J. H. 1970. Dinoflagellate cysts from post-glacial lake muds, Minnesota (U.S.A.). Rev. Palaeobot. Palynol., 10, 131-156.

Reid, P. C. 1974. Gonyaulacacean dinoflagellate cysts from the British Isles. Nova Hedwigia, 25, 579-637.

Reid, P. C. \& Harland, R. 1977. Studies of Quaternary dinoflagellate cysts from the North Atlantic. A.A.S.P. Contrib. Ser. 5A, 147-167.

Wall, D. \& Dale, B. 1968. Modern dinoflagellate cysts and the evolution of the Peridiniales. Micropaleontology, 14, 3, 265304. 